\title{
Study of Rendement of Red Ginger Essential Oil from Red Ginger Waste by Using Steam Distillation Process
}

\author{
Widayat Widayat ${ }^{*}$, Dita Ayu Sofiati ${ }^{2}$, Bambang Cahyono ${ }^{3}$ and Hantoro Satriadi ${ }^{1}$ \\ ${ }^{1}$ Department of Chemical Engineering, Faculty of Engineering, Diponegoro University, Semarang-Indonesia \\ ${ }^{2}$ Advanced Material Laboratory, Integrated Laboratory of Diponegoro University, Semarang-Indonesia \\ ${ }^{3}$ Department of Chemistry, Faculty of Science and Mathematics, Diponegoro University, Semarang-Indonesia
}

\begin{abstract}
This study aims to determine the value of rendement of red ginger essential oil from red ginger waste that has been dried through the steam distillation process. Red ginger waste from fresh red ginger that has been taken the juice then dried with the help of sunlight for 1,2,3 and 4 days. The dried red ginger waste then subjected to steam distillation for 3 and 7 hours to determine the rendement of the red ginger essential oil produced. Based on the study, the rendement of each essential oil on 3 hours distillation time were $0.2 \%$; $0.6 \% ; 1 \%$; and $0.8 \%$, while at 7 hours distillation time the rendement were $0.2 \% ; 0.6 \% ; 0.75 \%$; and $0.6 \%$. The rendement was differences because of in 7 hours time distillation; the essential oil could be degradation process so that the rendement was higher in 3 hours time distillation. The highest rendement was obtained by steam distillation of red ginger waste with 3 days of drying time.
\end{abstract}

Keywords: red ginger; essential oil; steam distillation; rendement

\section{INTRODUCTION}

An increase in the concentration of greenhouse gases (GHG) or better known as the effects of greenhouse gases in the atmosphere of the Earth has been one of the causes of global climate change. This phenomenon causes an increase in the earth's surface temperature which then causes negative effects of climate change, the natural environment and the social life of the community. In line with the development of social life, $\mathrm{CO}_{2}$ (carbon dioxide), methane and other non- $\mathrm{CO}_{2}$ gases also experience an increase in the quantity in the atmosphere [1]. This emission gas is generally produced from burning fossil fuels, industrial activities and waste from human activities.

The herbal medicine industry has long existed in Indonesia, not least in Central Java. Industries which use herbal plants whose juice is taken and then processed into medicinal products also produce solid waste. One herbal industry in Central Java produces around 17,000 $\mathrm{kg}$ of waste per day consisting of turmeric, ginger, and other spices. The use of porridge is only limited as a fuel that has a low heat value and as fertilizer [2]. On the other hand, there is still an essential oil content in waste that has high benefits, for example in red ginger waste.

Zingiber officinale Roscoe or commonly known as red ginger is one of several types of herbs that are available in Indonesia. Red Ginger is a plant that is developed in Asia and has been widely used in the food industries, medicine and cosmetics [3]. The distinctive aroma produced by the red ginger is the content of active compounds that can be used as a drug for pain relief and the amount of red ginger antioxidant which is made of red ginger widely used internationally.

The study has been doing by [4] they were analysis of performance and antioxydant activity of the red ginger which is mixed with other spices as a healthy drink. On the other hand, the red ginger essential oil is one of the most widely used international red ginger products [3]. Several methods have been used to extract the essential oils that found in red ginger, such as hydro distillation, steam distillation and distillation using organic solvents [5]. Steam distillation and hydro distillation are traditional methods that used to extract essential oils from plants. The disadvantage of this method is that there are losses of volatile components and increasing use of temperatures causes partially or totally structural damage to the essential oils produced [6]. However, this method has the advantage of being easy to use because it does not require a solvent, so there is no need to perform solvent separation techniques from the essential oils produced or it is cheaper than the other method and environmentally friendly.

Essential oils are commonly obtained from fresh or dried plants. [3] Conducted a method of hydro distillation on fresh ginger and dried ginger. Based on research conducted by [3], obtained the yield of $1.02 \%$ ginger oil from fresh ginger and $1.84 \%$ from dried ginger. In research conducted by [7] using steam distillation method with steam flow rate variation, obtained the highest yield of $2.43 \%$ for the lowest steam flow rate of $0.35 \mathrm{ml} / \mathrm{s}$.

${ }^{*}$ Corresponding author: widayat@live.undip.ac.id 
There have been numerous studies conducted [3] on the yield of essential oils produced during steam distillation and hydro distillation to extract essential oil from fresh ginger, but the potential possessed by residual ginger waste from traditional beverage making is still less attention. [8] was conducted a study on the potential of red ginger as a producer of starch which is beneficial for the human body because it contains bioactive compounds. The precipitated red ginger juice was taken and dried, and then the starch yielded $15.69 \%$ by weight. The starch production of the red ginger that has been done [8] left the waste the red ginger that has not been used optimally. Ginger waste still has potential because in general, Indonesian people only take the ginger extract, where fresh red ginger is grated and then squeezed for water. It is this potential that encourages the study of the value of the essential oil rendement which can be produced from the dried red ginger waste using the steam distillation method.

\section{METHOD}

\subsection{Materials}

Fresh Red ginger from local market in Semarang, Mineral water from local supermarket in Semarang, distilled water from Integrated Laboratory of Diponegoro University and $\mathrm{Na}_{2} \mathrm{SO}_{4}$ from Indrasari chemical store in Semarang.The equipment for experiment like presented in Fig 1. Capacity of production essential oil of 100 gr raw material.

\subsection{Distillation Process}

Fresh red ginger obtained from the local market in Semarang then cleaned and washed. The cleaned red ginger was shredded using electrically grated. The shredded ginger was added water with the ratio of 3:5 [8]. The homogeneous mixture of water and red ginger was squeezed and then the red ginger juice was deposited for 45 minutes. The resulted precipitate was separated from ginger water and dried into red ginger starch. Ginger water was stored as raw material for beverages. Red ginger waste dried in the room temperature for $1,2,3$, and 4 days. A total of $50 \mathrm{gr}$ of dried red ginger waste were distilled for 3 and 7 hours. The distillation process was carried out using a tool assembled in accordance with figure 1 . The heating temperature of the heating mantle was adjusted to $95^{\circ} \mathrm{C}$ with the volume of steam water was $900 \mathrm{ml}$. The distillation product was collected and separated between oil and water. Red ginger oil produced was calculated volume, added $\mathrm{Na}_{2} \mathrm{SO}_{4}$ to bind oil to not easily evaporate and stored in a closed container.

\subsection{Rendement Calculation}

Rendement of the essential oils can be calculated by equation 1

$$
\text { Rendement }=\frac{\text { oils from product }(\mathrm{ml})}{\text { Raw material }(\mathrm{gr})}
$$

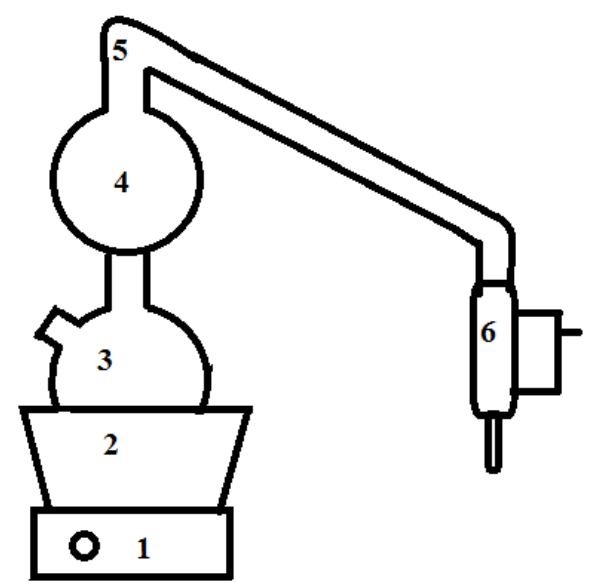

Fig. 1. Simple Steam Distillation
Information
1. Heater
2. Water bath
3. Steam water container
4. Sample container
5. Condenser
6. Collector

\section{RESULTS}

Table 1. The value of Rendement of Red Ginger Essential Oil

\begin{tabular}{ccc}
\hline \multirow{2}{*}{$\begin{array}{c}\text { Drying time } \\
\text { (day) }\end{array}$} & \multicolumn{2}{c}{ Rendement Value (\%) } \\
\cline { 2 - 3 } & 3 Hours & 7 Hours \\
Distillation & Distillation \\
\hline 1 & 0.2 & 0.2 \\
2 & 0.6 & 0.6 \\
3 & 1 & 0.75 \\
4 & 0.8 & 0.6 \\
\hline
\end{tabular}

Red ginger oil produced from red ginger waste has a high of rendement. This study proved that red ginger waste has the potential as a raw material for made red ginger essential oil as an alternative to reduce waste of red ginger waste. Based on table 1, the highest rendement was occurred on the distillation of red ginger waste with drying time 3 days, while on 2 days and 4 days drying time the rendement value was not much different. The lowest rendement resulted occurs in the drying time of ginger waste for 1 day. Based on experiments conducted by $[3,9,10]$, the value of essential oil yield on dried ginger is higher than fresh ginger. This is in line with research conducted by [9], where the longer drying time then the yield of ginger oil produced was also higher. According to [10], in general, the drying process on the material prior to distillation can increase or decrease the yield value of the essential 
oil. In this study, the length of the drying time, the higher of the rendement value. However, there was decreased the rendement in the dried material for 4 days because the longer drying time than cause losses the volatile compounds the material. In this study, the optimum drying time occurs within 3 days of drying. Based on the experimental results on the distillation time of 3 hours and 7 hours, the highest rendement value was obtained during the distillation time for 3 hours. The water content of materials was $12.31 \%$ caused more steam to the maximum contact with the material so that the content of the extract essential oils was more optimal.

The distillation time also affects the yield value of the resulting ginger oil. In this study, the length of the distillation time does not significantly affect the rendement value of red ginger oil produced. At drying of material 3 and 4 days, there was the difference of rendement value where 3 hours distillation get the rendement value bigger than the rendement value at 7 hours distillation.

The chemical composition of red ginger oil produced can be seen in Table 2. The most common compound in red ginger oil in this study is camphene of $24.16 \%$ and the least compound was borneol.

Table 2. Chemical Compositions of Red Ginger Oil from GC-MS Analysis

\begin{tabular}{ccl}
\hline No & Area (\%) & \multicolumn{1}{c}{ Name } \\
\hline 1 & 4.32 & Alpha-pinene \\
2 & 24.16 & Camphene \\
3 & 2.77 & Beta-myrcene \\
4 & 5.52 & 1,8-cineole \\
5 & 3.45 & dL-limonene \\
6 & 2.24 & Borneol \\
7 & 8.01 & Z-citral \\
8 & 2.59 & Geraniol \\
9 & 10.72 & E-citral \\
10 & 6.32 & Gamma-dodecalactone \\
11 & 15.75 & Benzene,1-(1,5-dimethyl-4- \\
& & hexenyl)-4-methyl \\
12 & 5.59 & Zingiberene \\
13 & 2.26 & Beta-bisabolene \\
14 & 6.01 & Beta-sesquiphellandrene \\
\hline
\end{tabular}

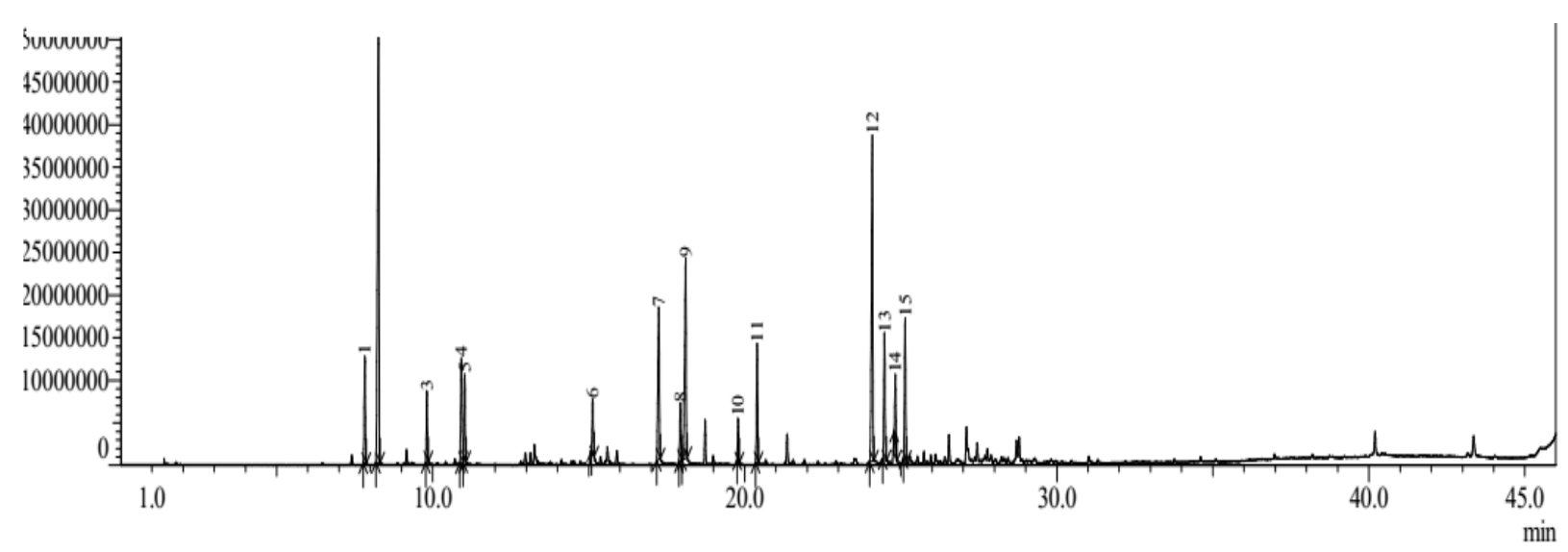

Fig. 2. Chromatogram for GC-MS Analysis of Red Ginger Oil

\section{CONCLUSIONS}

The red ginger essential oil can be produced from red ginger waste by using steam distillation process. The optimum drying time was 3 days and the optimum distillation time was 3 hours. The highest rendement was $1 \%$.

This research was supported by Diponegoro University with Strategi Nasional Grant with letter of assignment No. 101-117/UN7.P4.3/PP/2018. Authors were thank to Center of Research and Service Analysis Diponegoro University (CORES DU) for Gas Chromatography and Mass Spectrophotometry analysis.

\section{REFERENCES}

1. T. Nakata, D. Silva, and M. Rodionov. "Application of energy system models for designing a low-carbon society". Prog. in Energy and Combustion Sci. 37, 462-502 (2011)

2. A.N. Amir and P.F.Lestari. "Pengambilan Oleoresin Limbah Ampas Jahe Industri Jamu (PT Sidomuncul) dengan Metode Ekstraksi. Jurnal Teknologi Kimia dan Industri. 2 (3), 88-95 (2013)

3. O. Ekundayo, I. Laakso, and R. Hiltunen. "Composition of ginger (Zingiber officinale Roscoe) volatile oils from Nigeria". Flavour and Fragarance Journal. 3, 85-90 (1988) 
4. W. Widayat, B. Cahyono, H. Satriadi and S. Munfarida. "Antioxidant activity and total phenolic content in Red Ginger (Zingiber officinale) based drink". IOP Conf. Series: Earth and Environmental Science. 102 (2018)

5. M.L. Presti, S. Ragusa, A. Trozzi, P. Dugo, F. Visinoni, A. Fazio, G. Dugo, and L. Mondello. "A comparison between different techniques for the isolation of rosemary essential oil". J. Sep. Sci. 28, 273-280 (2005)

6. M. Gavahian, A. Farahnaky, K. Javidnia, and M. Majzoobi. "Comparison of ohmic-assisted hydrodistillation with traditional hydrodistillation for extraction of essential oils from Thymus vulgaris L". Innovative Food Sci. \& Emerging Technol. 14, 85-91 (2012)

7. M. A. Fitriady, A. Sulaswatty, E. Agustian, Salahuddin, and D. Y. F. Aditama. "Steam distillation extraction of ginger essential oil:
Study of the effect of steam flow rate and time process". International Symphosium on Applied Chemistry. 1-10 (2016)

8. W. Widayat, H. Satriadi, Syaiful, A. Kurnia and F. Driastuti. "Starch Production from Red Ginger (Zingiber officinale Rosc.)". Jurnal Bahan Alam Terbarukan. 7(1), 96-99 (2018)

9. I. Hasmita, Adisalamun, P. N. Alam, Satriana, Malinda, and M. D. Supardan. "Effect of drying and hydrodistillation time on the amount of ginger essential oil". International Journal on Advanced Sci. Engineering Information Technology. 5, 300-303 (2015)

10. M.M. Sourestani, M. Malekzadeh, and A. Tava. "Influence of drying, storage and distillation times on essential oil yield and composition of anise hyssop [Agastache foeniculum (Pursh.) Kuntzel]". J. Essent. Oil Res. 26, 177-184 (2014)

* Corresponding author: widayat@live.undip.ac.id 